\title{
GEREJA DALAM PERSIMPANGAN: LEMBAGA SWADAYA MASYARAKAT ATAU LEMBAGA ADIKODRATI PENGEMBAN MANDAT ILAHI
}

Imanuel Sukardi ${ }^{1}$, Samuel Purdaryanto ${ }^{2}$

Sekolah Tinggi Teologi Injili Indonesia Jakarta

Sekolah Tinggi Teologi Arastamar Bengkulu

ymsukardi@yahoo.com, ${ }^{2}$ samuelpurdaryanto@sttab.ac.id*

\section{Abstract}

Church must be understood as supernatural spritual institution as bearers of divinemandates on this earth, spiritual mandates and social mandates, be spiritual blessing and physical blessing. Church has taken the form of formal and legal institutions as such as social institutions. Then, the problems are the character and the impact of churches are not better than the social institution. Its because they lost their boot mandates. Those mandates originate and move from two church shahadas,love God and love others. The ambivalance among shahada and character,mandate and function cause churches are on intersection of become social institution or a spiritual institution. To back to their origin function, churches face two challenges. They are bravery to take off the deadly tradition,system, and theologies and then back to biblical tradition, system, and theologies. This study uses a qualitative research method with a descriptive analysis approach.

Key word: church, shahada, spiritual institution, social institution, divine mandate, spiritual mandate, social mandate, ambivalance, intersectiin,tradition,system.

\begin{abstract}
Abstrak
Gereja mestinya dimaknai sebagai lembaga rohani adikodrati pengemban mandat illahi di bumi, mandat spiritual menjadi berkat rohaniah dan mandat sosial menjadi berkat jasmaniah di tengah masyarakat. Gereja telah mengambil bentuk lembaga formal dan legal sebagai organisasi seperti halnya lembaga sosial masyarakat biasa. Problematikanya tabiat dan manfaat gereja sebagai lembaga tidak lebih baik dari lembaga sosial pada umumnya. Disinyalir karena gereja telah kehilangan dua mandat ilahinya sekaligus. Dua mandat tersebut berpangkal dan bergerak dari dua sila sahadat gereja yaitu kasih kepada Allah dan kasih kepada sesama. Terjadinya ambivalensi antara sahadat dan tabiat, antara mandat dan manfaat mengakibatkan gereja sebagaimana sekarang ini, dalam persimpangan antara lembaga sosial atau lembaga spritual. Untuk kembali keesensinya, gereja menghadapi dua tangtangan, keberanian melepaskan diri dari tradisi, sistem dan teologi yang mematikan dan kembali pada tradisi, sistem dan teologi alkitab. Penelitian ini menggunakan metode penelitian kualitatif dengan pendekatan deskriptif analisis.

\footnotetext{
${ }^{1}$ Dr. Imanuel Sukardi, M.Th, Ketua Sekolah Tinggi Teologi Injili Indonesia Jakarta, dosen Teologi Biblika, Misiologi \& Pertumbuhan gereja.

${ }^{2}$ Samuel Purdaryanto, M.Pd.K., M.Th, Dosen Misiologi \& Sejarah Gereja di Sekolah Tinggi Teologi Arastamar Bengkulu.
} 
Kata kunci: gereja, sahadat, lembaga rohani, lembaga sosial, mandat illahi, mandat spiritual, mandat sosial, ambivalen, persimpangan, tradisi, sistem.

\section{PENDAHULUAN}

Banyak yang harus dipastikan bahwa gereja bukan sekadar lembaga swadaya masyarakat melainkan lembaga adikodrati pengemban mandat illahi di bumi. Implementasi mandat ilahi di bumi adalah misi gereja yang orisinil. Konsekuensi tidak terelakan, jika gereja gagal atau abai menghidupi esensinya sebagai lembaga adikodrati pengemban mandat illahi di bumi maka gereja tidak lebih dari sekadar lembaga swadaya masyarakat sebagaimana pada umumnya. Bahkan menurut Robert S. Paul sebagaimana dikutip oleh Wijaya, "Gereja tidak memiliki alasan untuk berada, jika tanpa misinya". 3

Membandingkan gereja dengan lembaga swadaya masyarakat secara diametris seperti tomato to tomato terkesan tidak etis dan tidak adil. Karena seperti telah ditegaskan di atas, gereja adalah lembaga rohani dan adikodrati yang mana "Kristus sebagai penggagas, pendiri, pondasi, pemilik sekaligus sebagai pemimpinnya". ${ }^{4}$ Dalam konteks ini Kristus memiliki misi tersendiri yang khas dan khusus bagi gereja-Nya di bumi yang tidak boleh diingkari.

Tetapi seperti tersembunyi di depan mata dalam beberapa hal tertentu gereja tidak lebih baik dari lembaga swadaya masyarakat. Misalnya, lembaga swadaya masyarakat mengumpulkan dana untuk kepentingan misi kemanusiaan sedangkan gereja mengumpulkan uang demi kepentingan sendiri. Lembaga swadaya masyarakat berorentasi ke luar, membagi dan menolong sedangkan gereja berorentasi ke dalam, menyedot sumber daya dan memperkaya diri. Lembaga Swadaya Masyarakat lebih menjawab kebutuhan sosial dan lebih menyejarah dalam kehidupan nyata manusia sedang gereja lebih cenderung eksklusif dan pasif terhadap pergumulan masyarakat.

Atas dasar semua realitas tersebut di atas masyarakat setempat memiliki alasan kuat mengapa tidak memerlukan atau tidak mengharapkan kehadiran gereja lebih banyak lagi di lingkungannya. Kehadiran gereja justru cenderung dinilai dan dimaknai hanya sebagai ancaman ekspansi agamawi dan tradisi dari pada pembawa harapan baru, mengganggu kemapanan sosial dari pada jawaban yang dinantikan.

\footnotetext{
${ }^{3}$ Jonathan Wijaya Lo, Pemuridan Intensional Dalam Gereja Tradisional (Tangerang: UPH Press, 2018), 89.

${ }^{4}$ Y. M. Imanuel Sukardi, Pedoman Penanaman Gereja Baru Masa Kini (Surakarta: STT Berita Hidup, 2006), 2.
} 
Kehidupan, kekuatan dan dinamika gereja ada pada Allah sendiri, karena Dialah pendiri dan pemilik Gereja. ${ }^{5}$ Oleh karena itu gereja tidak dibenarkan memiliki agenda dan haluan sendiri melainkan tunduk pada maksud dan tujuan Allah mendirikan gereja-Nya. Tetapi gereja telah memilih dan mengambil bentuk sebagaimana organisasi pada umumnya yang lebih mencirikan lembaga swadaya masyarakat dari pada lembaga rohani adikodrati sebagai pengemban mandat ilahi di bumi.

Gereja berubah wujud menjadi organisasi yang dalam perkembangannya mengalami fragmentasi denominasi yang tidak terkendali dan tidak terinci lagi. Masing-masing melengkapi infrastruktur dan aparaturnya sendiri. Setiap gereja menciptakan pelayanan dan kebutuhannya sendiri, memperbanyak dan memperberat beban sendiri," termasuk pengadaan dan perawatan bangunan, pengangkatan dan penggajian pendeta, pembuatan dan pembiayaan program". 6 Dengan visi dan misi sendiri, memikirkan dan memperkuat diri sendiri menjadi ciri sekaligus sebagai konsekuensi yang tidak mungkin dihindari gereja sebagai organisasi.

David Hunt mendeskripsikan gereja sebagai organisasi seperti berikut: "Mereka mengumpulkan sumber daya finansial, mengangkat pemimpin karismatik, menetapkan struktur organisasi, pengamanan aset, sebuah kontruksi bangunan, dan sebuah inisiatif program pemasaran untuk menarik orang-orang masuk ke dalam gedung gereja untuk mengikuti berbagai variasi program dan kegiatan". ${ }^{7}$ Dalam arti lain kosekuensi dari bentuk yang telah dipilih untuk dirinya membuat gereja semakin tidak memadai dan tidak berdaya mengemban mandat illahi di bumi. "Tatkala bentuk gereja terlalu ditekankan dan kekuasaan Allah diabaikan, gereja hanya berfungsi sebagai komunitas sosial saja",

Dari beberapa pokok masalah di atas secara otomatis melahirkan beberapa pertanyaan mendasar sebagai berikut: Apakah gereja dengan segala eksistensinya sama dengan lembaga swadaya masyarakat? Mengapa gereja tidak berdaya menghidupi esensinya sebagai lembagai adikodrati pengemban mandat illahi di bumi?

\footnotetext{
${ }^{5}$ Chris Marantika, Teologi Pertumbuhan Gereja (Yogyakarta: STTII, n.d.), 61.

${ }^{6}$ Wolfgang Simson, Gereja Rumah Yang Mengubah Dunia (Jakarta: Metanoia, 2003), 45.

${ }^{7}$ David Hunt, "A Revolution in Church Multiplication in East Africa," Dissertation, April 17, 2017, accessed September 27, 2021, https://bgu.edu/dissertations/revolution-church-multiplication-eastafrica.

${ }^{8}$ Wijaya Lo, Pemuridan Intensional Dalam Gereja Tradisional, 192.
} 
Bagaimana caranya gereja bisa amanah dan memenuhi marwahnya sebagai lembaga adikodrati pengemban mandat illahi di bumi.

\section{METODE PENELITIAN}

Dalam dan melalui karya ilmiah ini peneliti mencoba menjawab berbagai pertanyaan di atas seobjektif mungkin. Pertama, menjelaskan apakah gereja dengan segala eksistensinya sama dengan lembaga swadaya masyarakat. Kedua, mendiskripsikan alasan-alasan mengapa gereja tidak berdaya menghidupi esensinya sebagai lembaga adikodrati pengemban mandat ilahi di bumi. Ketiga, mengusulkan bagaimana caranya gereja bisa amanah dan memenuhi marwahnya sebagai lembaga adikodrati pengemban mandat ilahi di bumi.

Untuk memenuhi tujuan di atas peneliti menggunakan pendekatan yang lazim disebut metode diskriptif kualitatif. Moleong menjelaskan penelitian kualitatif sebagai penelitian yang tujuannya memahami fenomena yang dialami oleh subyek penelitian. ${ }^{9}$ Adapun alasan penggunaan pendekatan tersebut karena problematika yang ada masih bersifat awal yang memerlukan penelitian untuk mendalami dan menemukan kesimpulan akhir yang valid. Tujuan penggunaan pendekatan yang dimaksud di atas adalah untuk menemukan dan menjelaskan fakta melalui pengumpulan data, yang mendalam dan objektif, di samping mencari pengertian yang mendalam tentang suatu gejala, fakta dan realita.

\section{HASIL DAN PEMBAHASAN}

Hasil dan pembahasan karya ilmiah ini diuraikan sebagai berikut:

\section{DUA SILA SYAHADAT GEREJA}

“Gereja adalah persekutuan Tuhan; awalnya, sejarahnya dan tujuan mulianya semua atas dasar inisiatif dan kuasa ilahi". ${ }^{10}$ Kebenaran tersebut mulai tidak disadari banyak gereja masa kini. "Mungkin ada gereja yang mengetahui inti persoalan gereja tetapi tidak jelas mengetahui tujuan Tuhan untuk gereja". ${ }^{11}$ Akar pangkal tujuan Tuhan bagi gereja-Nya ternyata tertempa ada pada dua sila sahadat yang Yesus deklarisasikan sendiri.

Sulit dipahami dan tidak mudah diterima oleh umat Kristen pada umumnya bahwa ternyata gereja memiliki sahadat terdiri iman (kepada Tuhan) dan ketaatan (terhadap hukum) atau berupa akidah dan kaidah. Mencermati secara mendalam

\footnotetext{
${ }^{9}$ Lexy J. Moleong, Metodologi Penelitian Kualitatif (Bandung: PT. Remaja Rosda Karya, 2017), 6.

${ }^{10}$ Robert.L Saucy, The Church in God's Program (Chcago: Moody Publisher, 1974), 19.

${ }^{11}$ Wijaya Lo, Pemuridan Intensional Dalam Gereja Tradisional, 29.
} 
pernyataan Yesus secara khusus dalam Markus 12:29-31 yang dilansir dari Ulangan 6:4-5 membawa pada sebuah kesimpulan bahwa Kristus memperkenalkan kredo orang percaya sebuah kombinasi iman dan ketaatan. Orang percaya mengimani bahwa Allah adalah esa (akidah) dan mentaati perintah-Nya, mengasihi Allah dan mengasihi sesama (kaidah). Teks dalam kitab Ulangan (Ul. 6:4-5) dilansir dalam Markus 12: 29-31 dengan menambahkan "dengan segenap akal budimu" dan menjadikan dua sila yakni mengasihi Tuhan Allah dengan segenap hati dan mengasihi sesamu manusia seperti dirimu sendiri. Kata yang diterjemahkan "dengarlah" dalam Ulangan 6:4 dari kata Ibrani "shema" yang berarti perintah mendengar untuk melakukan atau mendengar yang diikuti ketaatan. Akhirnya dikukuhkan sebagai kredo atau sahadat bagi orang Yahudi yang kemudian oleh Yesus diformat ulang menjadi dua sila diperuntukan bagi gereja.

Iman kepada Allah yang esa dan ketaatan terhadap perintah-Nya (Rom 1:5) dalam kredo gereja menuntut orang percaya mengasihi "Allah dengan segenap..." berarti mengasihi Dia tanpa sisa. Dan “mengasihi sesama seperti...” berarti mengasihi sesama berstandar diri sendiri. Apa yang dimaksud dengan mengasihi. Mengasihi adalah menjadi dekat dan memberi dengan melibatkan perasaan, pikiran dan kemauan. Allah mengasihi manusia itulah sebabnya Allah datang ke dunia menjelma menjadi manusia (menjadi dekat) dan menyerahkan nyawa-Nya sebagai tebusan (memberi) (Mark. 10: 45 bnd. Yoh. 3:16)

Yesus menetapkan bagaimana caranya gereja mengimplementasikan kasih vertikal dan horisontal tersebut. Satu-satunya cara mengasihi Allah melalui ketaatan (Yoh. 14:15) sedang satu-satunya cara mengasihi sesama dengan seperti terhadap diri sendiri (Mark. 12:31). Kasih dan ketaatan tidak bisa dipisahkan, jika mengasihi Allah maka mentaatinya. "Gereja adalah persekutuan komunitas orang-orang percaya untuk mentaati Kristus". ${ }^{12}$ Oleh karena itu apakah gereja memenuhi rencana Allah bagi dunia melalui diri-nya atau sebaliknya ditentukan oleh ketaatan terhadap segala perintah-Nya. "Kata kuncinya adalah ketaatan kepada perintah Allah". 13

\section{Mandat Ganda Gereja}

Gereja baik yang bersifat organisme maupun yang berbentuk organisasi adalah merupakan lembaga adikodrati pengemban mandat illahi, mandat spiritual sebagai

\footnotetext{
${ }^{12}$ George Patterson, Church Planting Through Obedience Oriented Teaching (W. Carey Library, 1981), 1.

${ }^{13}$ Samuel D. Faircloth, Church Planting for Reproduction (Longwood FL: Xulon Press, 2012), 24.
} 
pembagi keselamatan dan mandat sosial pembuat kesejahteraan di tengah masyarakat. Dean Wiebrath mengingatkan "Gereja anda hendaknya menjadi gereja Amanat Agung, firman Allah memerintahkanya, kebutuhan-kebutuhan dunia menuntutnya". ${ }^{4}$ Dua mandat ilahi tersebut berpangkal pada dan bergerak dari dua sila sahadat gereja, kasih kepada Allah dan kasih kepada sesama. Kasih kepada Allah dan kepada sesama merupakan alasan dan landasan, akar dan pangkal dua mandat ilahi bagi gereja-Nya, mandat spiritual dan mandat sosial, menjadi berkat rohaniah dan menjadi berkat jasmaniah di dunia. "Sebagian orang beranggapan bahwa mereka mengetahui persis apa yang salah dalam suatu gereja" ${ }^{15}$ sebagian lain sebaliknya merasa tahu persis apa yang benar dalam suatu gereja. Dua persepsi bersebelahan yang berpotensi menyesatkan apabila berbasis intuisi yang bersifat subyektif belaka. Parameter paling dasar dan paling obyektif bahwa gereja berada pada posisi yang benar atau sebaliknya adalah apakah gereja sedang menjalankan fungsi sebagai pengemban mandat ilahi.

Dua mandat ilahi sebagaimana telah dikatakan sebelumnya, mandat spiritual menjadi berkat rohaniah dan mandat ilahi sosial menjadi berkat jasmaniah bagi dunia, semua suku bangsa dan bahasa adalah tujuan utama Allah mendirikan gereja-Nya. Chris Marantika menegaskan, "Untuk mengimplementasikan programnya di dunia dan bagi dunia, Allah mendirikan lembaga khusus. Dalam Perjanjian Lama lembaga itu ialah umat Israel, dalam Perjanjian Baru lembaga unik itu ialah gereja."16

Dua mandat ilahi bagi gereja, berhulu pada dan bermuara dari dua sahadat gereja kasih kepada Allah dan kepada manusia. Karena jika gereja mengasihi Allah maka akan mentaati-Nya, jika gereja mentaati-Nya maka gereja akan melakukan perintah-Nya menjadi berkat rohaniah dengan pergi menjadikan semua bangsa muridNya untuk melakukan perintah-Nya (Mat. 28:19-20). Ketika gereja sedang pergi mengerjakan Amanat Agung gereja sedang mentaati, sedang mengasihi, sedang mengemban mandat illahi dengan demikian sedang pada posisi yang benar. "Gereja yang berhenti ke luar menjangkau semua orang, dengan demikian berhenti menjadi gereja yang benar". ${ }^{17}$

Demikian juga jika gereja mentaati-Nya maka gereja menjadi berkat jasmaniah dengan pergi menjadi dekat dan memberi kepada sesama. Berkat yang

\footnotetext{
${ }^{14}$ Dean Wiebracht, Menjawab Tantangan Amanat Agung (Yogyakarta: Penerbit ANDI, 1997), 12.

${ }^{15}$ Christian Schwarz, Pertumbuhan Gereja Alamiah (Jakarta: Metanoia, 1998), 21.

${ }^{16}$ Marantika, Teologi Pertumbuhan Gereja, 44.

${ }^{17}$ Edward R. Dayton and David Allen Fraser, Planning Strategies for World Evangelization (Grand Rapids, Michigan, United States: Wm. B. Eerdmans Publishing, 2003), 45.
} 
diwujudkan dengan memperhatikan, membangun dan meningkatkan keadilan, keamanan dan kesejahteraan masyarakat. Pemenuhan dua mandat illahi ini merupakan pengharapan bagi dunia, manusia tidak hanya memiliki kebutuhan keselamatan tetapi juga memiliki kebutuhan kesejahteraan. Gereja bisa memberikan dimulai dari mana paling terasa dibutuhkan. "Karena penginjilan bukanlah satu-satunya pelayanan kristiani di dunia ini, pelayanan yang konprenhensif termasuk meliputi peran serta aktif dalam segala bidang kehidupan manusia sangat diperlukan" ${ }^{18}$

Antoine de Saint-Exupery pernah berkata "Jika anda ingin membangun sebuah kapal, jangan memanggil orang untuk membeli kayu, menyiapkan peralatan, membagi tugas, dan mengatur pekerjaan, tetapi lebih baik ajarlah mereka untuk merindukan lautan yang tidak bertepi". ${ }^{19}$ Kasih kepada Allah dan kepada sesama adalah medan tanpa batas yang Yesus sediakan bagi gereja-Nya sekaligus sebagai alasan dan landasan untuk mengimplimentasikan mandat illahi di bumi. Adapun mandat ilahi yang dimaksudkan bertitiktolak dari dua sila sahadat gereja.

\section{Gereja Rekakarsa Manusia}

Gereja diinisiasi dan didirikan oleh Kristus, terdiri umat yang ditebus dan dipilih oleh-Nya, disatukan dan dianalogikan tubuh-Nya. Dalam perkembangan, atas prakarsa orang-orangnya telah mengambil bentuk bagi dirinya sendiri. Bentuk yang bersifat duniawi, berkeberadaan kasat mata dan berupa organisasi. "Gereja yang berada dalam ruang dan waktu, yang terdiri dari berbagai anggota gereja, organisasi, dan status keanggotaan gereja". ${ }^{20}$

Para ahli teologi berusaha mempertahankan keadikodratian gereja dengan membuat dikotomi antara gereja dalam arti organisme dan organisasi. Agustinus membedakan antara dua jenis gereja "gereja duniawi dan gereja surgawi, gereja dalam ruang dan waktu dan gereja sebagai kota Allah, pemerintahan Allah atau kerajaan

Allah...". ${ }^{21}$ Suatu usaha yang tidak sia-sia tetapi tidak pernah bisa menghapus fakta gereja reka karsa manusia. Gereja dalam bentuk institusi secara eksistensi menyerupai dan berperangi lembaga soaial masyarakat. Lebih ekstrim lagi Yonathan mengatakan "Jikalau gereja dibentuk oleh kumpulan manusia yang memiliki visi dan tujuan yang

\footnotetext{
18 Ibid., 77.

${ }^{19}$ Schwarz, Pertumbuhan Gereja Alamiah, 26.

${ }^{20}$ Wijaya Lo, Pemuridan Intensional Dalam Gereja Tradisional, 85.

${ }^{21}$ Ibid.
} 
sama, maka gereja tidak punya unsur rohani. Ini berarti gereja tidak ada bedanya dengan kumpulan sosial",22

Persepsi di atas bukan tanpa alasan karena pada dasarnya baik gereja secara organisasi maupun lembaga sosial pada umumnya memiliki bentuk dan landasan pendirian yang sama "sebagai organisasi masa dan berbadan hukum"23. Halloway menegaskan bahwa lembaga swadaya masyarakat adalah "Bentuk oraganisasi yang memperhatikan kepentingan masyarakat yang secara mandiri dan bukan mencari untung atau organisasi yang memberikan manfaat kepada masyarakat". ${ }^{24}$ Misi gereja sebagai organisasi ditentukan oleh bentuknya sebagai lembaga sosial masyarakat yang menuntut berperan memperhatikan kepentingan dan memberi manfaat bagi masyarakat. Karena peran lembaga swadaya masyarakat "paling mendasar adalah mendukung peningkatan kesejahteraan masyarakat". 25

Misi lembaga swadaya masyarakat pada umumnya sebenarnya linier dengan mandat sosial gereja. Sehingga gereja tidak salah dalam bentuknya sebagai organisasi kecuali bentuk tersebut menjadikan gereja tidak berdaya melaksanakan mandatnya di tengah masyarakat. Kelompok non Kristen memperhatikan orang-orang gereja adalah komunitas yang antik bahkan asing, karena menjadi komunitas yang lebih mengasihi tradisinya dari pada mengasihi masyarakat sekitar. ${ }^{26}$ Seperti dalam kutipan Simson, John Camble berkata "Banyak orang telah mengindikasikan bahwa salah satu penghalang terbesar bagi seseorang untuk percaya kepada Kristus adalah gereja mereka sendiri". ${ }^{27}$ Jika benar demikian maka gereja telah gagal mengemban mandat gandanya di dunia.

Oleh karena itu bisa menjadi pembanding seperti aple to aple, antara apa yang dilakukan gereja sebagai organisasi di tengah masyarakat dengan sesama lembaga sosial lainya, apakah gereja memiliki misi serupa dan menjalaninya sebaik mereka. Ada alasan yang cukup kuat untuk mengatakan bahwa jika gereja tidak memberi perhatian terhadap kesejahteraan masyarakat melainkan masing-masing hanya saling

\footnotetext{
22 Ibid.316.

${ }^{23}$ Muhamad Mirza, Lembaga Swadaya Masyarakat: Pengertian, Fungsi, ciri dan contoh, (Saintif. Com).

${ }^{24}$ Ari Ganjar Herdiansah, "PERAN ORGANISASI MASYARAKAT (ORMAS) DAN LEMBAGA SWADAYA MASYARAKAT (LSM) DALAM MENOPANG PEMBANGUNAN DI INDONESIA," Sosioglobal : Jurnal Pemikiran dan Penelitian Sosiologi 1, no. 1 (December 14, 2016): 54.

${ }^{25}$ Ibid., 58.

${ }^{26}$ George Hunter III, Church for the Chucrhed (Nashville, Tennessee, United States: Abingdon Press, 1996), 59.

${ }^{27}$ Simson, Gereja Rumah Yang Mengubah Dunia, 13.
} 
mementingkan dirinya sendiri, maka gereja tidak lebih dari sekedar lembaga sosial masyarakat yang paling buruk dari yang pernah ada.

\section{GEREJA DALAM PERSIMPANGAN}

Bagian ini merupakan bagian pokok bahasan sebagaimana pada judul di atas. Sehingga yang dimaksud dengan gereja dalam persimpangan adalah persimpangan antara sekadar tidak lebih hanya sebagai lembaga swadaya masyarakat seperti pada umumnya atau tetap pada esensinya sebagai lembaga rohani adidokdrati pengemban mandat illahi di bumi. Indikasinya adalah dalam praksis kehidupan sehari-hari apakah gereja masih konsisten mengerjakan dua mandat illahi atau sudah memutar kiblat fokus menghidupi diri sendiri sebagai organisasi. Jika gereja tidak lagi konsisten megerjakan dua mandat ilahi spiritual dan sosial maka gereja tidak lebih sekadar lembaga swadaya masyarakat paling buruk dari yang pernah ada.

\section{Ambivalensi atau kelindansi}

Miroslav Volf sebagaimana dikutip oleh Yohanes mengatakan, "Ketegangan antara ajaran yang dipercaya dengan perilaku kehidupan sehari-hari sebagai pengikut Kristus tidak bisa diabaikan. Keparcayaan iman Kristen merupakan dasar bagi praksis umat kristiani...". ${ }^{28}$ Mengasihi Allah dan sesama dogma atau fakta, seharusnnya dogma atau ajaran yang menjadi fakta. Apakah sebaliknya terjadi ambivalensi antara dogma dan fakta sehingga menjadi dogma atau ajaran, berbeda dengan yang dilakukan. Apabila terjadi ambivalensi dalam praksis kehidupan sehari-hari maka gereja sedang berada pada ketidakberdayaan mengemban mandat illahi. Sebaliknya apabila gereja sannggup mengkelindansikan antara dogma dan faka, dogma menjadi fakta dan fakta menjadi dogma, maka gereja sedang berada dalam kondisi kebugaran prima sehingga banyak yang bisa diharapkan untuk memenuhi tanggungjawabnya sebagai pengemban mandat illahi.

Yesus telah menetapkan parameter yang terukur terhadap implimentasi kasih kepada Allah dan kepada sesama. Batu uji kasih kepada Allah adalah ketaatan. Yesus menegaskan berulang-ulang dalam Yohanes 14 secara khusus dalam ayat 15 dengan mengatakan "Jikalau kamu mengasihi Aku, kamu akan menuruti segala perintah$K u$ ”. "Ketaatan adalah satu-satunya modus mengasihi Allah tidak ada yang lain, tidak

\footnotetext{
${ }^{28}$ Hendra Yohanes, "MODEL ORTODOKSI-ORTOPRAKSI-ORTOPATI: Usulan Model Berteologi Sebagai Cara Hidup Kaum Injili Di Dunia Pascakebenaran,” Jurnal Amanat Agung 15, no. 1 (June 1, 2019): 96.
} 
bisa ditukar tidak bisa ditunda". ${ }^{29}$ Jadi jelas sekali, dalam hal ini tidak perlu ahli tafsir maupun ahli kitab bahwa kasih bertolok ukur ketaatan, jika mengasihi Allah maka akan mentaati segala perintah-Nya.

Bagian paling sulit dari doktrin gereja adalah menghilangkan salah paham dan citra-citra mental buruk yang telah melandanya". ${ }^{30}$ Praduga paling masuk akal terhadap kondisi tersebut adalah sebagai akibat dari krisis ketaatan. Ketaatan memiliki implikasi logis baik interen maupun eksteren. Implikasi interen, ketaatan membawa pada tujuan kekal Allah bagi orang percaya yakni serupa dengan Kristus (Rom.8:29). Karena dengan semakin taat seseorang akan semakin berubah, semakin berbeda dan dengan demikian semakin menyerupai Kristus. Perlu diketahui bahwa "kehidupan yang diubahkan merupakan promosi terbesar dari sebuah gereja". 31

Implikasi eksteren, hanya dengan ketaatan gereja akan mengerjakan mandat ilahi spiritual yaitu menyelamatkan bangsa-bangsa di dunia yang tersisa. George Patterson menegaskan "Komitmen orang-orang Kristen kepada Kristus tidak akan pernah diwujudkan kecuali dibangun atas dasar ketaatan kepda perintah-perintahNya" ${ }^{32}$ Ketaatan mengerjakan Amanat Agung adalah satu-satunya ketaatan segera yang tidak bisa ditunda dan tidak bisa digantikan. Inti sari mandat ilahi spiritual bagi gereja adalah "Allah memberkati umat-Nya supaya menjadi berkat sampai berkat keselamatan itu diterima oleh setiap suku, kaum, bangsa, dan bahasa". 33

Atas dasar itu, "Tujuan utama gereja dalam kaitannya dengan dunia adalah penginjilan. "Hal ini dapat dipahami karena pemahaman Alkitab secara mendalam menunjukan bahwa gereja tak ubahnya sebagai suatu organisasi dunia lainnya bila penginjilan dunia tidak menjadi fokus utamanya. ${ }^{35}$ Mandat ilahi menjadi berkat rohani di bumi hanya bisa dipenuhi jika gereja mentaati perintah-Nya (Mat. 28:19-20 bnd Kis. 1:8), mentaati perintah-Nya hanya bisa dilakukan jika gereja mengasihi-Nya (Yoh. 14:15 bnd Rom. 1:5). Gereja yang kehilangan mandat dikarenakan kehilangan ketaatan, gereja yang kehilangan ketaatan dikarenakan kehilangan kasih. Oleh karena itu, pada umumnya gereja yang bertumbuh di atas rata-rata adalah gereja yang

\footnotetext{
${ }^{29}$ Y.M Imanuel Sukardi, STRATEGI PENANAMAN GEREJA EKSPANSIONAL (STT Baptis Jakarta, 2015), 8.

${ }^{30}$ Michael Griffiths, Gereja Dan Panggilannya Dewasa Ini (Jakarta: BPK Gunung Mulia, 2001), 2.

${ }^{31}$ Rick Warren, Purpose Driven Church (Malang: Gandum Mas, 2004), 228.

${ }^{32}$ Faircloth, Church Planting for Reproduction, 72.

${ }_{33}$ David David.K, Kingdom Life Style (Yogyakarta: Penerbi ANDI, 2015), 353.

${ }^{34}$ Saucy, The Church in God's Program, 91.

${ }^{35}$ Marantika, Teologi Pertumbuhan Gereja, 41.
} 
memiliki kasih lebih tinggi dibandingkan dengan gereja yang mandek dan bertahan atau bahkan menurun. ${ }^{36}$

Parameter kasih kepada Allah berbeda dengan parameter kasih kepada sesama. Kasih kepada Allah diukur dari ketatan sedang kasih kepada sesama diuji dari seperti terhadap diri sendiri. Seperti apa tabiat terhadap diri sendiri seperti itu juga tabiat terhadap sesama. Menjadi dekat dan memberi kepada sesama merupakan pelaksanaan mandat illahi sosial, menjadi berkat jasmaniah. "Diberkati supaya menjadi berkat kepada semua kaum di muka bumi ${ }^{37}$ merupakan ungkapan lain yang semakna dari mandat sosial bagi sesama. Menjadi dekat dan memberi kepada sesama berarti gereja menyejarah dalam kehidupan nyata masyarakat antara lain bisa menerima dan menjadi bagian masyarakat, menjawab kebutuhan dan membangun masyarakat, memperhatikan dan meningkatkan kesejahteraan hidup masyarakat dan sejenisnya. Inilah mandat bagi gereja untuk menjadikan dunia ini tempat yang baik untuk dihuni dimana masyarakatnya mengalami adil dan makmur. ${ }^{38}$

Grace Sumbung sebagaimana dikutip oleh Zega memberi contoh Gereja Injili Masehi di Minahasa, dalam mengemban mandat ilahi sosial dengan berkontribusi meningkatkan kualitas sumberdaya manusia bagi masyarakat dalam bentuk nyata seperti lewat pendidikan dengan membentuk balai kerja dan latihan ketrampilan. ${ }^{39}$ Dengan demikian pelayanan gereja tidak hanya berorentasi ke dalam melainkan juga ke luar berdampak bagi semua lapisan dan kelompok masyarakat. ${ }^{40}$ Fakta lain banyak Gereja yang tidak terbeban juga tidak sedikit yang tidak berdaya memenuhi mandat illahi sosial.

Salah satu alasan mengapa gereja tidak berdaya menjadi berkat spiritual maupun berkat sosial dikarenakan tidak sanggup menerjemahkan dogma menjadi fakta, mandat menjadi tabiat. Jika gereja konsisten menjalankan dua mandat ilahi, mandat spiritual dan mandat sosial, menjadi berkat rohaniah dan jasmaniah maka gereja sedang berada pada poros yang benar. Karena dua mandat tersebut berakar pangkal dan bergerak laju dari dua sahadat gereja kasih kepada Allah dan kepada sesama. Jadi apakah gereja sekadar lembaga swadaya masyarakat atau lembaga ilahi

\footnotetext{
${ }^{36}$ V.David Garrison, Church Planting Movements: How God Is Redeeming a Lost World (WIGTake Resources, 2007), 203.

${ }^{37}$ David.K, Kingdom Life Style, 351.

${ }^{38}$ Marantika, Teologi Pertumbuhan Gereja, 41.

39 Sabaria Zega, "Pentingnya Memahami Entrepreneurship Secara Biblikal Bagi Hamba Tuhan,"

KHARISMATA: Jurnal Teologi Pantekosta 1, no. 2 (March 6, 2019): 122.

${ }^{40}$ Ibid., 123.
} 
adikodrati sangat ditentukan oleh apakah gereja sedang mengimplementasikan sahadatnya atau sebaliknya.

\section{Tantangan Gereja}

Gereja menghadapi banyak tantangan dan tidak sedikit halangan yang tidak mudah diatasi untuk menjadi lembaga ilahi yang konsisten mengemban dua mandatnya di bumi. Ironisnya sebagian besar dari semua itu adalah ciptaan gereja sendiri, gereja "tanpa sadar" telah menciptakan banyak penghalang bagi dirinya sendiri sehingga menjadi lembaga yang tidak berdaya memenuhi misinya. Arthur P. Johnson menegaskan bahwa Gereja adalah alat pamungkas Tuhan untuk memperluas kerajaanNya di bumi. Johnson dalam karya Faircloth mengatakan, oleh karenanya gereja tidak diperboleh membuat program-program yang menjadi penghalang atau bahkan pengganti rencana-Nya tersebut melalui diri-nya. ${ }^{41}$ Fakta yang hampir tidak mungkin diakui dan tidak mudah disadari adalah bahwa gereja lebih banyak menciptakan penghalang-penghalang bagi dirinya sendiri sehingga meluluh-lantakan esensinya sebagai lembaga rohani pengemban mandat illahi.

Gereja memegang tradisi baik yang mematikan. Contoh klasik adalah gereja Efesus, gereja tersebut telah menggantikan mandat ilahi dengan tradisi-tradisi yang baik tetapi mematikan dirinya sendiri itulah sebabnya Yesus dengan tegas menuntut bertobat. Jika gereja Efesus tidak bertobat dari tradisi-tradisi baik yang mematikan maka Yesus akan menjatuhkan sangsi vital dan vinal.

Ada beberapa tradisi baik yang terindikasi mematikan gereja sebagai pengemban mandat illahi spiritual maupun sosial. Pertama, fokus ke dalam. Pada awalnya gereja selalu dimulai dari fokus ke luar menjangkau untuk menghasilkan petobat-petobat baru. Sampai di sini gereja berada pada fungsi yang benar. Akan tetapi setelah banyak petobat, gereja mulai mengumpulkannya ke dalam sebuah gedung untuk dipertahankan dan dilayani seumur hidup. Dengan kata lain gereja mengakhiri penginjilan ke luar dengan pelayanan ke dalam secara turun temurun.

Gejala dan fenomena umum gereja dimulai pergi ke area atau komunitas baru menjangkau masyarakat tertentu. Akan tetapi setelah itu mendirikan atau menyediakan bangunan gedung tempat mengumpulkan orang-orang secara rutin untuk dilayani dengan berbagai program. Atau seandainya masih pergi ke luarpun

\footnotetext{
${ }^{41}$ Faircloth, Church Planting for Reproduction.
} 
hanya sekadar mengisi kekosongan tempat duduk dan ruangan. ${ }^{42}$ Melayani orangorang di dalam tidak salah, kesalahannya berada pada ketika gereja menggantikan fokusnya, fokus ke dalam menggantikan fokus ke luar. Idealnya gereja fokus ke fokus, yaitu fokus ke dalam untuk atau demi fokus ke luar. Gereja mempersiapkan orang-orang dalam untuk menjangkau orang-orang luar.

Akan tetapi gereja tanpa ragu tanpa pertimbangan sengaja menciptakan banyak kegiatan, menciptakan banyak kebutuhan di dalam yang berakibat menghentikan langkahnya sebagai pengemban mandat ilahi. Berapa jiwa baru dimenangkan tidak pernah dipertanyakan namun berapa orang yang datang berkumpul mengikuti kegiatan selalu menjadi pusat perhatian. Bahkan gereja tidak segan-segan mengkonsentrasikan segala sumber daya yang ada hanya untuk acara dua jam ibadah saja. ${ }^{43}$

Jadi tradisi yang baik, fokus ke dalam tidak harus mematikan apabila fokus ke dalam tersebut demi dan untuk fokus ke luar. Hati-hati fokus ke fokus tersebut jangan menjadi alasan untuk terus fokus ke dalam dengan dalih belum siap ke luar. Karena fokus ke dalam tidak pernah ada batas kecuali setiap kegiatan dan kebutuhan pelayan ke dalam diproyeksikan dan diimplimentasikan ke luar untuk mengemban mandat ganda gereja.

Kedua, fokus pertumbuhan. Bertumbuh tidak salah tetapi menggantikan pelipatgandaan dengan pertumbuhan sebuah kesalahan. Bertumbuh tidak sama dengan berlipatganda tetapi berlipatganda selalu bertumbuh. Bahaya orentasi pertumbuhan adalah menempatkan pertumbuhan sebagai tujuan dan berusaha bertumbuh tanpa batas. Injil Yohanes 15:16 memberikan pemahaman bahwa orangorang dipilih sebelum dunia dijadikan bukan sekadar untuk bertumbuh melainkan untuk berbuah. Perlu diketahui bahwa tidak ada pertumbuhan tanpa batas, jika tidak menghasilkan buah maka cepat atau lambat gereja akan mati. Berbuah adalah menghasilkan kehidupan baru yang sama, orang percaya menghasilkan orang percaya baru dan gereja menghasilkan gereja baru.

Ada alasan yang nampak masuk akal sebagai dalih untuk tidak berlipatganda yaitu gereja yang pertama harus bertumbuh cukup besar dan cukup dewasa terlebih

\footnotetext{
${ }^{42}$ David L. Watson, Church Planting Essensial-Four Ways to Kill Church Planting, www.davidlwatson.org. Penelusuran 25 April 2020.

${ }^{43}$ Sukardi, Strategi Penanaman Gereja Ekspansional, 48.
} 
dahulu baru bisa berkorban dan mengerjakan pelayanan baru. ${ }^{44}$ Satu-satunya indikator kedewasaan adalah kemampuan berkembang biak. Itu adalah fakta yang menjadi kebenaran yang berlaku bagi gereja. Orang Kristen yang dewasa adalah orang Kristen yang menghasilkan orang Kristen baru, gereja yang dewasa adalah gereja yang menghasilkan gereja baru.

Pertumbuhan sering disalahartikan sebagai kesehatan sebuah gereja. Pertumbuhan hanyalah salah satu indikasi kehidupan sedangkan kehidupan yang sehat adalah kemampuan memenuhi fungsi hidup itu sendiri. Seperti halnya gereja, gereja yang sehat adalah gereja yang sanggup memenuhi fungsi sebagai pengemban mandat ilahi di bumi. Rick Waren menetapkan indikator yang sangat tepat bagi kesehatan gereja yaitu bahwa salah satu cara terbaik untuk mengukur atau mengevaluasi kesehatan sebuah gereja adalah dari kapasitasnya mengutus dan berapa jumlah orang yang digerakan melaksanakan Amanat Agung bukan dari jumlah anggota yang memenuhi tempat duduk. ${ }^{45}$

Orentasi pada pertumbuhan memiliki keanehan tersendiri secara alami tidak bernaluri dan tidak berpikir pelipatgandaan melainkan berobsesi gereja megah. Jika bernaluri dan berpikir pelipatgandaan maka tidak akan berorentasi pada pertumbuhan karena pelipatgandaan sendiri selain memenuhi kodrat mandat sebagai gereja juga sudah meliputi pertumbuhan. Gereja megah tidak salah kecuali menjadi penyebab invalidnya dan tidak berfungsinya gereja memenuhi panggilannya. Gereja tidak akan menjangkau dan menyelesaikan Amanat Agung hanya dengan pertumbuhan dan penambahan melainkan dengan gerakan pelipatgandaan. Gereja memiliki tujuan permanen yang dinyatakan dalam Matius 28:19-20, ayat yang dikenal sebagai Amanat Agung, merupakan perintah Allah terpenting bagi gereja untuk menjadikan semua bangsa umat-Nya. ${ }^{46}$

Gereja mega sama sekali bukan jaminan gereja akan berbuah atau berlipatgandaan melainkan justru semakin mematikan perannya pembawa pembaruan spiritual dan pembangunan sosial di tengah masyarakat. Karena gereja jenis ini meskipun sanggup menghimpun banyak orang dan berhasil mengumpulkan banyak uang namun pada saat sama dengan sendirinya meningkatkan berbagai jenis

\footnotetext{
${ }^{44}$ Garrison, Church Planting Movements: How God Is Redeeming a Lost World, 195.

${ }^{45}$ Warren, Purpose Driven Church, 37.

${ }^{46}$ Ron Jenson and Jim Stevens, Dinamika Pertumbuhan Gereja (Malang: Gandum Mas, 2006), 55.
} 
pelayanan dan bermacam jenis kebutuhan sehingga menjadi sangat rumit dan sangat mahal akibatnya sulit bereproduksi dan tidak mudah bermultiplikasi. ${ }^{47}$

Pelipatgandaan adalah idenya bukan pertumbuhan, gerakan pelipatgandaan adalah sejalan dengan tujuan bukan pertumbuhan, pelipatgandaan yang berkelanjutan adalah cara mencapai tujuan bukan pertumbuhan. Bukan gereja yang bertumbuh melainkan "gereja yang mulai berkarya dan melayani dalam demensi yang diutus yang mulai memahami tujuan dan takdir dari keberadaannya sebagai gereja." ${ }^{48}$ Ketika gereja fokus pada pertumbuhan bukan gerakan pelipatgandaan yang berkelanjutan sebenarnya gereja sedang menuju ke arah lain dari arah yang seharusnya, menghentikan Amanat Agung bukan mengerjakan untuk menyelesaikannya.

Ketiga, fokus pada keanggotaan. Fokus pada keanggotaan merupakan ekses yang tidak bisa dihindari dari gereja yang fokus ke dalam dan pertumbuhan. Gereja rela membayar harga yang harus dibayar untuk memuaskan, menambahkan dan mempertahankan anggota. Kecenderungan yang paling permanen adalah bagaimana mencetak loyalis-loyalis dan aktivis-aktivis gereja, indoktrinasi dan intimidasi untuk setia dan siaga kepada gereja. Anggota menjadi fokus perhatian dan pengajaran menjadi prioritas pelayanan tetapi melakukan perintah-Nya sungguh terabaikan. Dalam Matius 28:19-20, Yesus sangat lugas menegaskan "ajarlah mereka untuk melakukan segala yang telah Ku perintahkan kepadamu".

Gereja tidak bisa lari dari bahkan identik dengan pusat pengajaran. Ketaatan dan pengajaran dua hal yang masih bisa diperdebatkan tetapi ada perbedaan yang jelas antara fokus pengajaran dan fokus ketaatan. Pengajaran bersifat penanaman pengetahuan sedang ketaatan berupa penanaman DNA tindakan. Ketaatan hanya bisa diDNAkan tidak bisa diintruksikan. Jefffery Quester mengingatkan bahwa Yesus tidak memerintahkan untuk mengetahui segala perintah-Nya melainkan mengajar orang-orang percaya mentaati segala perintah-Nya. Ada perbedaan besar antara mengajarkan mengetahui dengan mengajarkan melakukan. Orang-orang percaya harus diajarkan mentaati segala yang diperintahkan-Nya. ${ }^{49}$

Dalam sejarahnya tidak pernah berubah, ketaatan adalah tuntutan Allah yang utama dan terutama karena merupakan dasar dan awal dari semua moralitas Kristen,

\footnotetext{
${ }^{47}$ Sukardi, Strategi Penanaman Gereja Ekspansional, 49-50.

48 Jhon Eckhardt, Gereja-Gereja Rasuli yang Baru, 61.

49 Jeffrey Quaster, Gerakan Allah Pada Masa Kini, n.d., 120-121.
} 
dasar dan awal mengerjakan Amanat Agung. ${ }^{50}$ Fokus pada keanggotaan cenderung menekankan ketaatan kepada gereja dan agama dari pada ketaatan kepada Kristus. Itulah sebabnya bagi gereja yang fokus keanggotan kehadiran lebih diperhatikan dari pada karakter, kesetiaan bergereja jauh dipentingkan dari pada kerohanian, keaktifan mengikuti program-program gereja sangat diutamakan dari pada kesalehan, loyalitas kepada gereja diprioritaskan dari pada moralitas.

Gereja yang mengutamakan keanggotaan dengan meninggalkan ketaatan kepada Kristus akan mematikan gerakan menuju tujuan. Karena hanya jika ada ketaatan maka Amanat Agung dikerjakan. David Watson menjelaskan, bahwa penanaman gereja-gereja baru, lahirnya petobat-petobat baru tidak akan pernah terjadi secara signifikan kecuali anggota-anggota diajar mentaati segala perintah-Nya. Ketaatan kepada Kristus diajarkan dalam tindakan dan perkataan di depan umum maupun pribadi kepada setiap orang percaya. Gereja harus menunjukkan ketaatannya kepada Kristus dalam setiap keputusan yang diambil dan dalam setiap program yang dibuat tanpa memperdulikan konsekuensinya. ${ }^{51}$

Fenomena umum gereja sibuk membuat program pemasaran, menciptakan dan menawarkan berbagai macam pelayanan bagaimana menarik dan mempertahankan angota, bagaimana membuat gereja nampak lebih bergairah dan nampak lebih hidup. Menekankan ketaatan memberi ketakutan tersendiri akan kehilangan anggota tetapi ketaatan kepada Kristus cepat atau lambat justru melipatgandakan anggota. Karena ketaatan kepada Kristus membuat hidup orang Kristen semakin berubah dan berbeda bukan sekedar semakin agamis dan aneh di depan masyarakat. Sehingga dengan demikian gereja memiliki gravitasi tinggi ketika pada saat yang sama mentaati Amanat Agung menjangkau yang tersisa.

Gereja memilih sistem baik yang mematikan. Perlu diakui bahwa gereja memiliki masalah yang sangat komplek, sangat rumit seperti benang kusut tidak tahu dari mana cara memperbaiki. ${ }^{52}$ Salah satu penyumbang masalah terbesar adalah sistem denominasi yang dipilihnya sendiri. Sistem denominasi adalah sistem baik yang mematikan. Baik karena sistem denominasional mengatur, mengorganisir dan menata gereja sebagai organisasi menjadi terstruktur, tertip dan terukur, lebih efektif

\footnotetext{
${ }^{50}$ Sukardi, Strategi Penanaman Gereja Ekspansional, 5.

51 David L. Watson, Church Planting Essensials-Four ways to kill Church Planting, www.davidlwatson.org. diakses April 2020.

52 Wijaya Lo, Pemuridan Intensional Dalam Gereja Tradisional, 30.
} 
dan efisien dalam melakukan apa yang diklaim sebagai tugas-tugasnya. Tetapi dalam kehidupan sehari-hari antar sesama orang percaya maupun peran gereja sebagai pengemban mandat illahi denominasi terindikasi menjadi penghalang dari banyak segi.

Meskipun tidak seluruhnya dan sepenuhnya denominasi yang ada buruk tetapi denominasi banyak menimbulkan masalah adalah benar. ${ }^{53}$ Dalam hidup sehari-hari denominasi sering mengganggu dan membatasi dalam merefleksikan kasih Kristus antar sesama orang percaya, antar sesama gereja karena alasan organisasi. Sistem denominasi juga merusak interdependensi sesama anggota tubuh Kristus, masingmasing mementingkan dan mempertahankan hidup sendiri-sendiri. Sehingga ada denominasi yang kaya raya ada denominasi yang masuk kategori fakir miskin, ada denominasi yang besar ada denomnasi yang kecil di samping saling berkompetisi berebut eksistensi.

Dalam kaitanya dengan ketaatan terhadap Amanat Agung, sistem denominasi membuat gereja sangat lemah dan sangat lamban, tidak menyeluruh dan tidak merata setiap gereja karena tergantung kondisi sendiri-sendiri. Situasi tersebut tidak bisa dihindari dikarenakan gereja terbebani menghidupi organisasi dan denominasi masing-masing. Itulah sebabnya pendekatan secara denominasional dalam mengerjakan Amanat Agung belum berhasil meskipun telah dilakukan beratus-ratus tahun sejak reformasi protestan yang dimulai tahun $1517 .{ }^{54}$ Pengutusan denominasi menggantikan pengutusan tubuh Kristus sehingga sangat membatasi jumlah yang diutus dan jangka waktu pengutusan karena sangat ditentukan kemampuan denominasi. Penanaman gereja lebih identik dengan penanaman denominasi dari pada penanaman kerajaan Allah itu sendiri. Dengan demikian ekspansi dogma dan budaya lebih dominan karena setiap denominasi memiiki dogma dan budaya sendiri sehingga banyak menghadapi tantangan di lapangan. Sehingga gereja menjadi tidak efektif dalam menuntaskan Amanat agung. ${ }^{55}$

Jika kembali kepamahaman gereja standar biblika maka sistim umat lebih tepat dari pada sistem organisasi atau denominasi. Alasannya sistem umat lebih biblika

\footnotetext{
${ }^{53}$ J.Habert Kane, Understanding Christian Mission (Grand Rapids, Michigan, United States: Baker Book House, 2013), 352.

${ }^{54}$ David L. Watson, Why Denomination can not Complete the Comission, www.davidlwatson.org. Penelusuran 21 April 2019.

55 Samuel Purdaryanto, "Efektivitas Gereja Dalam Menuntaskan Amanat Agung," TEMISIEN 1, no. 2 (September 30, 2021): 97.
} 
karena mengekspresikan keberadaan semua orang percaya dalam kesatuan tanpa batas (termasuk batasan bangsa, bahasa bahkan kasta).sebagaimana dianalogikan tubuh Kristus. Umat yang maksudkan di sini adalah semua orang yang dipilih, dipanggil Allah, disatukan dengan Kristus dan didiami oleh Roh Kudus. ${ }^{56}$ Sehingga satu sama lain memiliki ikatan emosi universal, memiliki loyalitas universal, memiliki komitmen universal dan memiliki tanggungjawab universal. Sebagai umat satu sama lain dalam kesatuan fakta bukan dogma karena tidak tersandera doktrin , tradisi dan organisasi masing-masing.

George A. Patterson secara operasional mendefinisikan gereja adalah komunitas orang-orang percaya untuk mentaati Kristus. ${ }^{57}$ Dalam kaitannya dengan gereja sebagai pengemban mandat illahi, sisten umat akan membuat lebih efektif dan lebih efisien. Karena sistem umat gereja menjadi lebih sederhana tidak rumit, lebih murah tidak banyak terbebani keuangan, lebih fleksibel tidak berinfrastruktur, lebih dinamis tidak stagnasi, sehingga sangat memungkinkan mengalami duplikasi dan multiplikasi dalam kecepatan tinggi dan berkelanjutan. Menurut Neil Cole Gereja yang tidak bersifat tradisional dan tidak berpola denominasional, paling siap memenuhi wilayah karena bersifat informal dan mudah bergerak, dari segi keuangan tidak terbebani secara berlebihan dan mudah ditanam diberbagai latar belakang sehingga bereproduksi dan menyebar dengan cepat. ${ }^{58}$

Dalam bentuknya gereja tidak terikat, bisa dalam kelompok kecil bisa dalam kelompok besar, tidak diharuskan beribadah di tempat resmi tidak disalahkan beribadah di tempat non formal selama tidak mengkianati sistem umat. Karena dengan menggantikannya sistem umat menjadi sistem denominasi gereja menghambat atau bahkan menghentikan panggilanya sebagai pengemban mandat illahi. Parameter sentral gereja ideal sepanjang masa adalah gereja mula-mula yang berasas keumatan (bnd is. 2: 41-47).

\section{KESIMPULAN}

Penggagas, pondasi, pendiri, pemimpin dan pemilik gereja adalah Kristus. Kristus memiliki tujuan bagi pendirian gereja dan gereja bertanggungjawab memenuhinya. Tanggung jawab gereja adalah sebagai pengemban mandat illahi spiritual dan mandat illahi sosial yang berpangkal pada dan bergerak dari dua sila

\footnotetext{
${ }^{56}$ Saucy, The Church in God's Program, 19.

${ }^{57}$ Patterson, Church Planting Through Obedience Oriented Teaching, 1.

${ }^{58}$ Neil Cole, Organic Church (Yogyakarta: Penerbi ANDI, 2006), 27-28.
} 
sahadat gereja. Jika gereja tidak memenuhi tanggung jawabnya sebagai pengemban mandat illahi spiritual dan sosial maka gereja tidak lebih dari lembaga swadaya masyarakat paling buruk dari yang pernah ada. Tantangan gereja yang lain yang tidak kalah mematikan adalah sitem denominasional. Karena sistem ini menggangu dan menghalangi implimentasi program ilahi melalui gereja-Nya di dunia. Oleh karena itu gereja perlu mempertimbangan sistem umat sebagai pengganti sistem denominasi. Karena sistem umat lebih dekat dengan definisi dan analogi alkitab, lebih informal dan lebih universal, lebih praktis dan lebih dinamis sehingga gereja sanggup memulihkan marwah dan kaidahnya.

\section{DAFTAR PUSTAKA}

Cole, Neil. Organic Church. Yogyakarta: Penerbi ANDI, 2006.

David.K, David. Kingdom Life Style. Yogyakarta: Penerbi ANDI, 2015.

Dayton, Edward R., and David Allen Fraser. Planning Strategies for World Evangelization. Grand Rapids, Michigan, United States: Wm. B. Eerdmans Publishing, 2003.

Faircloth, Samuel D. Church Planting for Reproduction. Longwood FL: Xulon Press, 2012.

Garrison, V.David. Church Planting Movements: How God Is Redeeming a Lost World. WIGTake Resources, 2007.

Griffiths, Michael. Gereja Dan Panggilannya Dewasa Ini. Jakarta: BPK Gunung Mulia, 2001.

Herdiansah, Ari Ganjar. "Peran Organisasi Masyarakat (Ormas) Dan Lembaga Swadaya Masyarakat (Lsm) Dalam Menopang Pembangunan Di Indonesia." Sosioglobal : Jurnal Pemikiran dan Penelitian Sosiologi 1, no. 1 (December 14, 2016): 49.

Hunt, David. "A Revolution in Church Multiplication in East Africa." Dissertation, April 17, 2017. Accessed September 27, 2021.

https://bgu.edu/dissertations/revolution-church-multiplication-east-africa.

Hunter III, George. Church for the Chucrhed. Nashville, Tennessee, United States: Abingdon Press, 1996.

Jenson, Ron, and Jim Stevens. Dinamika Pertumbuhan Gereja. Malang: Gandum Mas, 2006.

Kane, J.Habert. Understanding Christian Mission. Grand Rapids, Michigan, United States: Baker Book House, 2013.

Marantika, Chris. Teologi Pertumbuhan Gereja. Yogyakarta: STTII, n.d. 
Moleong, Lexy J. Metodologi Penelitian Kualitatif. Bandung: PT. Remaja Rosda Karya, 2017.

Patterson, George. Church Planting Through Obedience Oriented Teaching. W. Carey Library, 1981.

Purdaryanto, Samuel. "Efektivitas Gereja Dalam Menuntaskan Amanat Agung." TEMISIEN 1, no. 2 (September 30, 2021): 95-112.

Quaster, Jeffrey. Gerakan Allah Pada Masa Kini, n.d.

Saucy, Robert.L. The Church in God's Program. Chcago: Moody Publisher, 1974.

Schwarz, Christian. Pertumbuhan Gereja Alamiah. Jakarta: Metanoia, 1998.

Simson, Wolfgang. Gereja Rumah Yang Mengubah Dunia. Jakarta: Metanoia, 2003.

Sugiyono, Sugiyono. Metode Penelitian Kuantitatif Kualitatif Dan R D. Bandung: Alfabeta, 2006.

Sukardi, Y. M. Imanuel. Pedoman Penanaman Gereja Baru Masa Kini. Surakarta: STT Berita Hidup, 2006.

Sukardi, Y.M Imanuel. Strategi Penanaman Gereja Ekspansional. STT Baptis Jakarta, 2015.

Warren, Rick. Purpose Driven Church. Malang: Gandum Mas, 2004.

Wiebracht, Dean. Menjawab Tantangan Amanat Agung. Yogyakarta: Penerbit ANDI, 1997.

Wijaya Lo, Jonathan. Pemuridan Intensional Dalam Gereja Tradisional. Tangerang: UPH Press, 2018.

Yohanes, Hendra. "Model Ortodoksi-Ortopraksi-Ortopati: Usulan Model Berteologi Sebagai Cara Hidup Kaum Injili Di Dunia Pascakebenaran.” Jurnal Amanat Agung 15, no. 1 (June 1, 2019): 77-110.

Zega, Sabaria. "Pentingnya Memahami Entrepreneurship Secara Biblikal Bagi Hamba Tuhan.” KHARISMATA: Jurnal Teologi Pantekosta 1, no. 2 (March 6, 2019): $118-132$. 